\title{
Emphatic Segments and Emphasis Spread in Rural Jordanian Arabic
}

\author{
Dr. Anas Huneety \\ Dr. Bassil Mashaqba \\ Corresponding author: Dr. Anas Huneety, The Hashemite University- Jordan, 313, Department of English Language and Literature \\ The Hashemite University, Zarqa, Jordan; Email: Hneety@live.com; almashaqba@live.com
}

\section{Doi:10.5901/mjss.2016.v7n5p294}

\section{Abstract}

This paper attempts to provide an analysis of emphasis spread in Juffin Arabic, henceforth JA, a rural dialect spoken in Juffin village in the north of Jordan. The study considers a sample of 50 minimal pairs that differ solely in the feature [emphatic] in different word positions; the 50 minimal pairs were tested in the speech of 12 ideal participants, males and females, who are 40 years and above. The study reveals that the class of emphatics in JA comprises a primary set of /ț/ $/ \mathrm{s} /$ and / $/ \mathrm{d} /$, and a secondary set of /!l, / $/ \mathrm{l}$, and $/ \mathrm{m} /$. Where emphasis spreads bidirectionally in JA, rightward is bounded by the set of /i/, /I/, /y/, and $/ \check{S} /$.

\section{Introduction and Literatures Review}

The term emphasis is a distinctive feature of Semitic languages which defines segments produced with a primary articulation in the dento-alveolar ${ }^{1}$ region and a secondary articulation that involves some constriction in the upper region of the pharynx (Card 1983; McCarthy 1994; Davis 1995; Watson 1999; Huneety 2015; Mashaqba 2015). The outcome of this is two contrastive classes of phonemes that share the same place and manner of articulation and differ only by the feature [+emphatic]. Acoustically, lowering of F2 value of the vowel that is adjacent to the emphatic is a key cue to the perception of emphatics (Cf. al Masri and et al (2011).

A big deal of literature has examined emphasis theoretically and instrumentally, e.g. Obretch (1968), Al-Ani (1970), Card (1983), McCarthy (1994), Zawaydah (1999), Watson (1999) and Dickens (2007). Different terms have been used to refer to emphasis, including velarization (Obrecht 1968), pharyngealization (Al Ani 1970; Watson 2002; Dickins 2007), uvularization ( McCarthy 1994; Shahin 1997; Zawaydah 1999), retracted tongue root (Ladefoged 1975; El-Dalee 1984), and dorsalization (Halle et al 2000). The most prominent one is pharyngealization because this reflects the fact that pharynx is barrowed during articulating these sounds. Terms used by arab grammarians include ?ițbāq, which refers to 'the raising and spreading of the tongue' ( Lehn 1963:29, cited in Al-Masri and Jongman2004), and tafxim which was coined to distinguish the non-emphatic sonorants /// and / $/$ / from their emphatic counterparts in Quranic recitations (AlHamed 2003)

Although it is agreed that the tongue dorsum is the active articulator of emphatic segments, there is some controversy over the actual place of pharyngeal constriction, whether it is the upper pharynx 'uvularization/velarization' (Zawaydeh 1998), or the lower pharynx 'pharyngealization' (Bellem 2007).

Emphatics fall into two subclasses: primary emphatics and secondary emphatics. Primary emphatics comprise the set of pharyngealized coronals /ț/, /ș/, / $\mathbf{d} /$, and /ḍ/ which are traditionally viewed as primary or phonemic and they cause spreading of emphasis to other segments (Davis 1995; Watson 1999; Bellem 2007). They contrast respectively with the following set of plain coronals $/ \mathrm{t} /, / \mathrm{s} /, / \mathrm{d} /$, and $/ \mathrm{d} /$. Secondary emphatics refer to segments that show phonemic contrast in specific environments where they are adjacent to the low vowels /a/ and läl (Bellem 2007: 43; Davis 2009: 637). Thus, where the set of coronal emphatics $/ t ̦ /, / s \mathbf{l} / / \mathrm{d} /, / \mathrm{d} /$ and $/ \mathrm{r} /$ occurs in different vocalic environments, the rest of the emphatics occur only in the vicinity of the low back vowel /a/, e.g., Paḅ 'father', yamma 'mother' (Davis 2009; Youssef 2013: 101). The most common marginal emphatics in the literature are /r $/ / \mathrm{l} /, / \mathrm{Im} /$, and / $/ \mathrm{b} /$, and basically they occur in the vicinity of the low vowels /a/ and /ä/ (Davis 2009: 637).

Emphasis spread is an assimilatory process where emphatic segments spread the feature [+RTR] to neighboring segments (al Khatib 2008: 1). In other words, an emphatic segment propagates the emphasis feature and spreads it over to the next segments which might spread it in return to attached affixes. Arabic dialects exhibit some differences in terms

${ }^{1}$ Davis (1995) maintains that the class of emphatics comprises not only dentals and alveolars but also labials. 
of the source of emphasis, and the extent to which high vocoids may block the spread of emphasis. In Muslim Baghdadi Arabic (Blanc 1964), emphasis spreads minimally over the syllable and maximally over the entire phonological word. It might affect affixes where there is a word-final primary emphatic. Emphasis is potentially blocked by lil, /îl plus palatals.

Providing an acoustic analysis of uvularisation spread in cAmmāni Arabic using four words, Zawaydeh (1998) considers the spread of uvularisation from the set of coronal consonants / $/ \mathrm{d} / \mathrm{It} / \mathrm{l} / \mathrm{d} /$ and $/ \mathrm{s} /$ and from the uvular stop /q/. She finds out that the word is the domain of emphasis spread as she finds out that none of the high vocoids can block rightward and leftward spread of emphasis. She further adds that uvularisation spread of emphasis does not exhibit any gradiency in leftward emphasis, i.e. F2 of the vowel is low irrespective of its distance from the emphatic segment. In contrast, rightward emphasis is gradient where F2 values are lower for vowels adjacent to the emphatic. Examining the acoustic correlates of emphasis in Jordanian Arabic, Al-Masri and Jongman (2004) show that emphasis is bidirectional and exhibits as for most other dialects considered above rightward/leftward asymmetry; emphasis is blocked by the set of high segments: li/ and /ul. Watson (2002) shows that leftward emphasis in Cairene Arabic is absolute within the stem whereas rightward emphasis is blocked by nontautosyllabic vocoids: li/ and /yl.

In southern and northern Palestinian Arabic, emphasis works bidirectionally, exhibiting a rightward/leftward asymmetry (Davis 1995). Like most Arabic dialects, leftward emphasis is absolute, but rightward emphasis is blocked by a set of opaque segments. These segments are /il, /yl, lj/, and /š/ in southern Palestinian Arabic, but they are lil, /ul, /yl, $/ s ̌ /$ and $/ w /$ in northern Palestinian Arabic.

Examining Wadi Mousa Arabic, Huneety (2015) shows that emphasis spreads bidirectionally in the dialect, minimally over the syllable and maximally over the phonological word. Surveying literature on emphasis spread, we find that Arabic dialects exhibit differences in the source, direction and blockers of emphasis. Hence, this study aims to examine the triggers, the direction and the blockers of emphasis in Juffin Arabic and then show how the dialect differs from neighbouring Arabic dialects.

\section{Material and Methodology}

To properly characterise emphasis spread in JA, the researchers recruited 12 ideal participants, 6 males and 6 females, who are natives of JA plus two language informants (consultants). To get a comprehensive account, the data were collected from participants of various ages (40-70 years) who represent the various families of Juffin village. All these participants are 40 years or above to ensure that they maintain the key features of the dialect, i.e., unaffected by aspects of modern life that have changed some of the linguistic features of young generation's speech (cf. Huneety 2015; Mashaqba 2015). Participants' level of education ranges from primary education (7 participants) to secondary education (5 participants). The researchers ensured that informants are healthy, have no speech impediments and can provide sufficient data for this study.

A sample of 50 minimal pairs that differ only in terms of the feature [ \pm emphatic] was prepared, including monosyllabic words, bisyllabic words, trisyllabic words, and words which include potential blockers of emphasis in other Arabic dialects. Emphatic segments were also chosen in different word positions to check the domain and directionality of emphasis. Two methods of collecting data were used in this study. In the first method, all informants were asked to read the list of minimal pairs embedded in the sentence biddi ahutt kilmit . ... bjumla mufida 'I am going to use the word... in a useful sentence'. The second method involves recording conversations with 6 participants comprising various social topics, e.g., Bedouin ways of life, agriculture, foods, tourism and modern life. During these conversations, the researchers asked frequent questions that involved participants to use words having emphatic segments. Observation of how people speak the dialect is also employed as a source of data.

\section{Discussion and Results}

Examining the data collected shows that the set of emphatics in JA comprises /ț//ș/ and /d d/, which exhibits phonemic contrast respectively with /t/ and /d/; /s/ and /z/; and / $\underline{t} /$ and $/ \mathbf{d} /$ in all vocalic positions, as in:

(1) $/ t ̦ /$, It/ țāb 'to heal': tāb 'to repent'

Iț/, Id/ batțal 'to change his mind': baddal 'to exchange'

|ș/, Is/ șāa 'to hunt': sād 'to control'

$\mid$ și, |z| ṣād 'to hunt': zād 'to add'

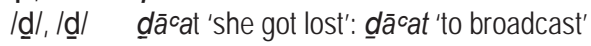

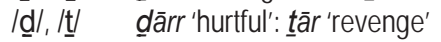

The primary emphatics occur in different vocalic environments, as shown in Table (1) below: 
Table (1): Distribution of emphatic segments in JA

\begin{tabular}{|c|c|c|}
\hline Word-initially & Word-medially & Word-finally \\
\hline tașwīr 'photograghy' & $y$-șawwit 'to vote' & bāș 'bus' \\
\hline țār 'to fly' & bin-țawwir 'we develop' & hatț ' to put' \\
\hline dallat 'she stayed' & gādi 'judge' & hadd 'luck' \\
\hline țūb 'block' & $n$-șir 'we become' & marbūț'tied \\
\hline dēm 'oppression' & hẹett-ak 'your wall' & xētt 'thread' \\
\hline
\end{tabular}

The class of emphatics comprises a secondary set of $/ ! l, / \mathrm{r} /$, and $/ \mathrm{m} / \mathrm{m}$. The emphatic /!! occurs with the different lexemes of the word Allah al!lah 'God', e.g. ballah 'really?', or next to a following /a/, /ā/ or /u/ preceded by back consonants /x/, /g/ or Ig̀l, e.g., xāl 'maternal uncle', and gạ̄l 'to say', šug̣ul 'work', bag̉u! 'mule', daxa! 'to seek refuge', gamu! 'flea', xạlawi 'mobile phone'. The emphatic /!! is found in non-derived nouns with historical $a^{*}$, ${ }^{\star} \bar{a}$ and *u, but /// shows before *i, e.g. *xilāf > xlāf 'argument, *qulūb > glūb 'hearts'. The flap /ṛ/ and the nasal $/ \mathrm{m} /$ occur in a few words in the vicinity of the low vowel /a/ and /āl, e.g. ḥabb 'to kiss', marad 'illness', mạyy 'water'.

Emphasis spreads bidirectionally in JA. It spreads minimally over the syllable and maximally over the word. Table (2) presents a set of minimal pairs that differ in \pm emphasis feature to show the domain of emphasis in JA. The spread of emphasis is indicated by an underline.

Table (2): Domain of Emphasis in JA

\begin{tabular}{|c|c|}
\hline Emphatic segments & Plain segments \\
\hline bașș 'to look' & bass 'only' \\
\hline hēțt 'wall' & hẹeț 'non-word' \\
\hline șamm 'non-word' & samm 'poison' \\
\hline țalla 'look' & talla 'hill' \\
\hline hatt ' to put' & hatt 'to erode' \\
\hline batț 'duck' & batt 'to take a final decision' \\
\hline dall 'to get lost' & dall 'to humiliate' \\
\hline dallal 'to misguide' & dallal to humiliate' \\
\hline
\end{tabular}

Emphasis spreads over suffixes only when immediately adjacent to an emphatic trigger; prefixes, however, fail to be emphatic even when they are tautosyllabic with an emphatic trigger. Consider the examples given in Table (3) below:

Table (3): The spread of emphasis into suffixes

\begin{tabular}{|c|c|}
\hline Emphatic segments & Plain segments \\
\hline balaș-hum 'he stole them' & balas-hum 'he told them a secret about someone' \\
\hline bās.hum 'their bus' & bās-hum 'he kissed them' \\
\hline hat -li 'he put to me' & hatt-li 'he eroded to me' \\
\hline xallaș-ha 'he saved her' & xallas-ha 'non word' \\
\hline țam-li 'he filled up something' & tam-li 'something is done' \\
\hline șallā-li 'he prayed to me' & sallā-li 'he entertained someone on my request' \\
\hline cattal-li 'he made something out of door' & cattal-li 'he made someone carry something' \\
\hline$y$-șalli 'he is praying' & $y$-salli 'he entertains' \\
\hline$y$-xașiș-u 'they specialize' & $y$-xasis-u 'they lose weight' \\
\hline 1-țārig 'for Tariq' & I-tārig 'nonword' \\
\hline
\end{tabular}

As in many other Arabic dialects (cAbbādi Arabic: Sakarnah 1999; Wadi Mousa Arabic: Huneety 2015; Wadi Ramm Arabic: Mashaqba 2015), leftward spread of emphasis is absolute in the dialect, i.e. emphasis spreads without being blocked by any segment. Consider the examples given in Table (4) below: 
Table (4): Leftward emphasis spread in JA

\begin{tabular}{|l|l|}
\hline Emphatic segments & Plain segments \\
\hline hatț 'to put' & hatt 'to erode' \\
\hline$\underline{\text { hafíd } \text { [proper name] }}$ & hafĩd 'grandson' \\
\hline$\underline{\text { šāș 'car' }}$ & šās non-word \\
\hline mallaș 'to let someone escape' & mallas 'to touch something softly' \\
\hline$\underline{\text { rabbaț 'to tie' }}$ & rabbat 'she brought up' \\
\hline$\underline{\text { balaș 'to steal' }}$ & balas 'to tell a secret' \\
\hline
\end{tabular}

In contrast to leftward emphasis that is unbounded in the dialect, a set of opaque segments impedes rightward emphasis: the palatal vocoids /il, /ī/ and /yl, and the palato-alveolar /šl. This contrasts with al-Masri and Jongman (2004) who show that rightward emphasis is blocked by the high vowels /i/ and /ul, and Huneety (2015) where it is blocked by the set of high segments lil, /y/ and /šl. Consider Table (5) below which shows how the opaque segments /il, /îl, /y/ and /š/ impede the rightward spread of emphasis in JA Arabic.

Table (5): Rightward emphasis spread in JA

\begin{tabular}{|l|l|}
\hline Emphatic & Gloss \\
\hline$\underline{\text { dayyac }}$ șāyim & 'to miss' \\
\hline țāyil & 'fasting' \\
\hline țayyib & [proper name] \\
\hline țilc-at & 'tender hearted' \\
\hline șāahạ & 'she went' \\
\hline$\underline{\text { dill }}$ & 'to reconcile' \\
\hline cațšān & 'shadow' \\
\hline țašššah & 'thirsty' \\
\hline țawwal & 'outing' \\
\hline
\end{tabular}

By contrast, emphasis spread is absolute in some Arabic dialects such as: cAbbādi Arabic (Sakarnah 1999) and Cairene Arabic (Youssef 2013). Table (6) below compares the impact of the opaque segments in both JA and cAbbādi Arabic (Sakarnah 1999).

Table (6): Rightward emphasis spread in JA and cAbbādi Arabic (Sakarnah 1999)

\begin{tabular}{|c|c|c|}
\hline cAbbādi Arabic & JA Arabic Arabic & Gloss \\
\hline șayyar & șayyar & 'to let something grow' \\
\hline țilc-u & țilc-u & 'they came out' \\
\hline cțšān & cțšāān & 'thirsty' \\
\hline țayyāra & țayyāra & 'plane' \\
\hline țili & țili & 'kid (m.)' \\
\hline
\end{tabular}

Watson (2002) shows that emphasis in Șancāni Arabic reaches the preceding word, particularly where word-final stop is immediately followed by a pharyngealised coronal and in phrases invoking God. To check the spread of emphasis to preceding words, minimal pair tests of phrases that differ in the emphasis feature were examined. The analysis of data shows that emphasis spreads optionally to a preceding word in phrases invoking God, e.g. in šâl!la in šâl! 'a 'God willing',

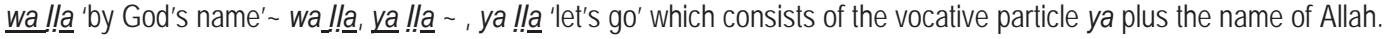
However, spread of emphasis fails to reach a preceding word in other cases.

\section{Conclusion}

This paper has examined emphatic segments and emphasis spread in Juffīn Arabic spoken in the north of Jordan. The

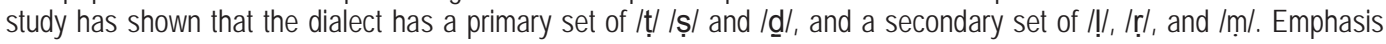
spreads bidirectionally in the dialect maximally over the word and minimally over the syllable. Whereas leftward emphasis 
is absolute, rightward emphasis is blocked by the set $/ \mathrm{li}$, $/ \mathrm{i} /$, $\mid \mathbf{s} /$, and $/ \mathrm{y} /$. Suffixes become emphatic when they are tautosyllabic with an emphatic segment. The study would recommend examining emphatic segments and emphasis spread in Bedouin Jordanian dialects in the northeast of Jordan where the influx of thousands of Syrian refuges is increasing. It would also recommend examining the phonological aspects of JA.

\section{References}

Al-Ani, S. (1970). Arabic phonology: An acoustical and physiological investigation. The Hague, Mouton.

Al-Hamed, G. (2003). Al-dirasāt al-șawtiyyah cind culamā? al-tajwīd. Amman: Dar Ammar

Al Khatib, Sam. (2008). 'On the directionality of emphasis spread'. In Proceedings of the 2008 annual conference of the Canadian Linguistic Association, pp. 1-10.

Al-Masri, M., and Jongman, A. (2004). 'Acoustic correlates of emphasis in Jordanian Arabic: Preliminary results'. In Agwuele, W. et al, (eds.). Proceedings of the 2003 Texas Linguistics Society Conference. Somerville, MA: Cascadilla Proceedings Project. 96-106.

Al-Masri, M, and Jongman, A. (2004). 'Acoustic correlates of emphasis in Jordanian Arabic: Preliminary results.' Proceedings of the 2003 Texas Linguistics Society Conference. Somerville, MA: Cascadilla Proceedings Project, pp.96-106.

Bellem, A. (2007). Towards a comparative typology of emphatics across Semitic and into Arabic dialect phonology. Ph.D thesis, University of London.

Blanc, H. (1964). Communal dialects in Baghdad, Cambridge, Harvard UP.

Card, E. A. (1983). A phonetic and phonological study of Arabic emphasis. Ph.D dissertation, Cornell University.

Davis, S. (1983). A phonetic and phonological study of Arabic emphasis. Ph.D dissertation, Cornell University.

Davis, S. (1995). 'Emphasis spread and grounded phonology'. Linguistic Inquiry, 26, 465-498.

Davis, S. (2009). 'Velarization'. The Encyclopedia of the Arabic Language 4, 636-638, Brill: Leiden

Dickins, J. (2007). Sudanese Arabic: Phonematics and syllable structure. Wiesbaden: Harrassowitz.

El-Dalee, M. S. (1984). The feature of retraction in Arabic. PhD Dissertation, University of Indiana, Bloomington.

Halle, M., Bert V. and Andrew W. (2000). 'On feature spreading and the representation of place of articulation'. Linguistic Inquiry 31: $387-444$.

Huneety, A. (2015). The phonology and morphology of Wadi Mousa Arabic. Ph.D dissertation, Salford University.

Jongman, A, et al. (2011). 'Acoustics and perception of emphasis in Urban Jordanian Arabic'. Journal of Phonetics 39.1 : 85-95.

Ladefoged, P. (1975). A course in phonetics. New York: Harcourt Brace Jovanovich.

Lehn, W. (1963). 'Emphasis in Cairo Arabic'. Language 39, 29-39.

Mashaqba, B. (2015) The phonology and morphology of Wādi Ramm Arabic. Ph.D dissertation, Salford University.

McCarthy, J. (1994) 'Variation and changes in Arabic urban vernaculars'. In: M. Haak et al (eds.). Approaches to Arabic dialects: Collection of Articles presented to Manfred Woidich on the Occasion of his Sixtieth Birthday, Leiden: Brill, 177-206.

Obrecht, D.H. (1968). Effects of the Second Formant on the Perception of Velarization Consonants in Arabic. The Hague: Mouton.

Sakarnah, A. K. (1999). Phonological aspects of cAbady Arabic, a Bedouin Jordanian dialect. Ph.D dissertation, University of Wisconsin.

Shahin, K. (1997). Postvelar harmony: An examination of its bases and crosslinguistic variation. Ph.D. diss., University of British Columbia.

Watson, J. C. E. (1999). 'The directionality of emphasis spread in Arabic'. Linguistic Inquiry, 30, 289-300.

Watson, J. C. E. (2002). The phonology and morphology of Arabic. Oxford: Oxford University Press.

Youssef, I. (2013). Place assimilation in Arabic: Contrasts, features, and constraints. Ph.D dissertation, University of Tromsø.

Zawaydeh, B. (1998). 'Gradient uvularization spread in Ammani-Jordanian Arabic'. In Benmamoun, E., Eid, M. and Haeri, N. (eds.). Perspectives on Arabic Linguistics XI: 117-41. Amsterdam: John Benjamins.

- (1999). The phonetics and phonology of gutturals in Arabic. Ph.D dissertation, Indiana University, Bloomington, IN. 